\title{
Using positive deviance (PD) to reduce antibiotic resistant organisms: the Canadian PD project
}

\author{
P Reason ${ }^{1}$, L Rykert ${ }^{1}$, TCPP Group ${ }^{2}$, M Gardam ${ }^{2 *}$ \\ From International Conference on Prevention \& Infection Control (ICPIC 2011) \\ Geneva, Switzerland. 29 June - 2 July 2011
}

\section{Introduction / objectives}

5 acute care hospitals were recruited to implement PD (at 6 sites) to determine whether it can reduce healthcareassociated (HA) AROs, specifically methicillin-resistant $S$. aureus (MRSA), vancomycin-resistant Enterococci (VRE), and C. difficile.

\section{Methods}

Four-month HA-ARO rates, the volume of alcohol hand rub and soap used, and the number of gowns and gloves used, were collected at baseline and then for 12 months prospectively. Social network mapping was conducted at the project start and end. Qualitative staff interviews were conducted at the project end. The percent change from baseline in quarterly HA-ARO rates were measured from September 2009 to December 2010. Process measures were collected and measured in a similar fashion.

\section{Results}

Of the 6 sites, 5 implemented PD as planned, while one was unable to, largely due to organizational restructuring. Three of the 5 sites sustained decreases in HAAROs of $25 \%, 41.2 \%$ and $63.9 \%$. Rates at the $4^{\text {th }}$ site were unchanged, while the fifth site had a VRE outbreak, which resulted in a large increase in the overall HA-ARO rate. HA-MRSA decreased by $100 \%$ at 2 hospital sites; HA-VRE decreased by $100 \%$ at 2 sites; and HA-C. difficile decreased at 3 sites by $53 \%, 51.9 \%$ and $23 \%$. The 1 site that measured hand hygiene compliance had a $53.2 \%$ rate increase. Interestingly, decreasing HAARO rates did not clearly correlate with the process indicators.

\footnotetext{
${ }^{2}$ Infection Prevention and Control, University Health Network, Toronto, ON, Canada
}

Full list of author information is available at the end of the article

\section{Conclusion}

PD has been successfully used in a number of settings facing complex problems. We have shown it to be successful in reducing HA-AROs in Canadian acute care facilities where the organizational climate allowed it to be implemented.

\section{Disclosure of interest}

None declared.

\section{Author details}

${ }^{1}$ Infectious Disease Prevention and Control, Ontario Agency for Health Protection and Promotion, Canada. ${ }^{2}$ Infection Prevention and Control, University Health Network, Toronto, ON, Canada.

Published: 29 June 2011

doi:10.1186/1753-6561-5-S6-050

Cite this article as: Reason et al:: Using positive deviance (PD) to reduce antibiotic resistant organisms: the Canadian PD project. BMC Proceedings 2011 5(Suppl 6):O50.

Submit your next manuscript to BioMed Central and take full advantage of:

- Convenient online submission

- Thorough peer review

- No space constraints or color figure charges

- Immediate publication on acceptance

- Inclusion in PubMed, CAS, Scopus and Google Scholar

- Research which is freely available for redistribution
C Biomed Central

C 2011 Reason et al; licensee BioMed Central Ltd. This is an open access article distributed under the terms of the Creative Commons Attribution License (http://creativecommons.org/licenses/by/2.0), which permits unrestricted use, distribution, and reproduction in any medium, provided the original work is properly cited. 